\title{
Pengaruh Moralitas Individu, Pengendalian Intern Dan Budaya Etis Organisasi Terhadap Kecenderungan Kecurangan Akuntansi
}

\author{
Ni Komang Ayu Anita Dewi ${ }^{1}$ \\ Fakultas Ekonomi dan Bisnis \\ Universitas Udayana, Indonesia. \\ Email: anitadewi193@gmail.com
}

\author{
Made Gede Wirakusuma² \\ Fakultas Ekonomi dan Bisnis \\ Universitas Udayana, Indonesia.
}

\begin{abstract}
ABSTRAK
Kecurangan dapat dilihat dari bentuk kebijakan yang disengaja dan tindakan yang bertujuan untuk melakukan penipuan atau manipulasi yang dapat merugikan pihak lain. Kecurangan merupakan tindakan penipuan yang disengaja, umumnya dalam bentuk suatu kebohongan, penjiplakan dan pencurian. Tujuan penelitian ini adalah untuk menguji pengaruh moralitas individu, pengendalian intern, dan budaya etis organisasi pada kecenderungan kecurangan akuntansi. Populasi yang digunakan adalah 23 KSP yang terdapat di Tegallalang, Kabupaten Gianyar. Metode pengumpulan data menggunakan kuisioner, teknik analisis regresi linier berganda digunakan dalam. Hasil penelitian menunjukkan moralitas individu, pengendalian intern dan budaya etis organisasi berperngaruh negatif pada kecenderungan kecurangan akuntansi. Hal ini berarti semakin baik moralitas individu, pengendalian intern, dan penerapan budaya etis organisasi pada KSP, maka akan dapat mengurangi tingkat kecenderungan kecurangan akuntansi yang terjadi pada KSP di Kecamatan Tegallalang.
\end{abstract}

Kata Kunci : Moralitas Individu; Pengendalian Intern; Kecenderungan Kecurangan Akuntansi; Budaya Etis Organisasi.

\section{Effects of Individual Morality, Internal Control and Organizational Ethical Culture on the Tendency of Accounting Fraud}

\begin{abstract}
Fraud can be seen from a deliberate form of policy and actions that aim to commit fraud or manipulation that can harm other parties. Fraud is an intentional act of fraud, generally in the form of a lie, plagiarism and theft. The purpose of this study was to examine the effect of individual morality, internal control, and organizational ethical culture on accounting fraud tendencies. The population used is 23 KSP in Tegallalang, Gianyar Regency. Methods of data collection using questionnaires, multiple linear regression analysis techniques used in. The results of the study show that individual morality, internal control and the ethical culture of the organization negatively affect accounting fraud tendencies. This means that the better the individual morality, internal control, and the application of organizational ethical culture in KSP, it will be able to reduce the level of accounting fraud tendencies that occur in KSP in Tegallalang District.
\end{abstract}

Keywords: Individual Morality; Internal Control; Accounting Fraud Tendency; Organizational Ethical Culture.

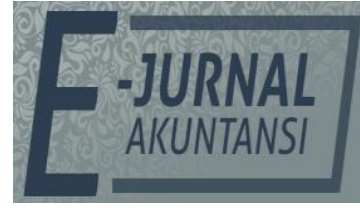

E-JA

e-Jurnal Akuntansi e-ISSN 2302-8556

Vol. 8 No. 2

Denpasar, Oktober 2019

Hal. 64-77

Artikel masuk: 19 Juni 2019

Tanggal diterima: 02 Agustus 2019 


\section{PENDAHULUAN}

Kecurangan akuntansi dalam era globalisasi sudah mendapat perhatian. Adanya kecurangan pada perusahaan ataupun instansi pemerintah terjadi akibat berkembangnya bisnis dan kemajuan teknologi dengan terbukanya peluang usaha. Prawira (2014) mengatakan organisasi dan lembaga mengalami kerugian akibat terjadinya kecurangan akuntansi. Tujuan melakukan penipuan dan manipulasi dilihat dari adanya kebijakan yang disengaja (Thoyibatun, 2012).

Tindakan penipuan yang disengaja, umumnya dalam bentuk suatu kebohongan, penjiplakan dan pencurian disebut fraud (Widjaja, 2013). Terdapat opini bahwa fraud dapat dikatakan sebagai tendensi korupsi dalam definisi dan teminologi karena keterlibatan beberapa unsur yang terdiri dari pengungkapan fakta-fakta menyesatkan, pelanggaran aturan atau penyalahgunaan kepercayaan, dan omisi fakta kritis. Sistem kerja yang terbuka dijadikan peluang bagi pelaku yang akan membuat kecurangan. Orang dalam yang biasanya menjadikan system sebagai siasat untuk melakukan kecurangan. System yang terbuka dijadikan kesempatan untuk melakukan pengawasan terhadap system yang berjalan (Kumaat, 2011).

Salah satu variabel yang diduga dapat mempengaruhi kecurangan akuntansi yakni moralitas individu, pada individu dengan penalaran moral rendah dalam kondisi terdapat elemen pengendalian intern cenderung tidak akan melakukan kecurangan akuntansi karenaa takut perbuatannya akan terdeteksi oleh pengendalian intern organisasi dan akan mendapat sanksi hukum (Prawira, 2014). Variabel pengendalian intern yang rendah terdapat pengendalian intern yang juga rendah dapat menjadi pemicu terjadinya kecurangan (fraud).

Peluang untuk melakukan kecurangan sangat besar dan dapat dikurangi dengan adanya system pengendalian intern yang baik (Widiyaswari, 2017). Sikap dan perilaku seorang individu yang akan menjadikan budaya organisasi dapay berjalan sesuai tujuan organisasi disebut dengan budaya etis organisasi (Pristiyanti, 2012). Budaya dapat difungsikan sebagai penyatu pengendalian dalam setiap karyawan. Koperasi sebagai salah satu bentuk organisasi ekonomi sudah tentu mempunyai tujuan yang jelas yang hendak dicapai. Koperasi yang tidak sehat dan bahkan mengalami kebangkrutan penyebab utamanya

pada kecurangan pengelolaan keuangan yang diduga karena lemahnya moralitas individu dan pengendalian intern koperasi masih rendah.

Kasus yang terjadi di Koperasi Putra Amerta yang termasuk koperasi simpan pinjam di Jalan Sriwidari No. 14 Tegallalang Gianyar mengalami masalah mengenai penggelapan uang sebesar delapan belas milyar rupiah, kasus ini terjadi pada Juli 2017 dilakukan oleh sekretaris sekaligus pengelola Koperasi Putra Amerta yang merupakan warga Banjar Pujung Kaja Desa Sebatu Kecamatan Tegallalang Kabupaten Gianyar, akibat perbuatannya Koperasi Simpan Pinjam Putra Amerta harus berakhir paksa karena pengurus ditetapkan sebagai tersangka oleh Derektorat Reserse Kriminal Umum Polda Bali.

Koperasi yang tidak sehat dan bahkan mengalami kebangkrutan penyebab utamanya pada kecurangan pengelolaan keuangan yang diduga karena lemahnya moralitas individu dan pengendalian intern 
koperasi masih rendah. Kasus yang terjadi di Koperasi Putra Amerta yang termasuk koperasi simpan pinjam di Jalan Sriwidari No. 14 Tegallalang Gianyar mengalami masalah mengenai penggelapan uang sebesar delapan belas milyar rupiah, kasus ini terjadi pada Juli 2017 dilakukan oleh sekretaris sekaligus pengelola Koperasi Putra Amerta yang merupakan warga Banjar Pujung Kaja Desa Sebatu Kecamatan Tegallalang Kabupaten Gianyar, akibat perbuatannya Koperasi Simpan Pinjam Putra Amerta harus berakhir paksa karena pengurus ditetapkan sebagai tersangka oleh Derektorat Reserse Kriminal Umum Polda Bali.

Berdasarkan data di Dinas Koperasi dan UKM Kabupaten Gianyar 2018, jumlah koperasi di Kabupaten Gianyar sebanyak 1218 unit, yang terdiri dari 983 koperasi aktif dan 235 koperasi tidak aktif. Pada tahun 2018 ada sebanyak 15 koperasi yang telah dibubarkan karena sudah tidak aktif lagi. Koperasi yang berdiri di daerah Tegallalang yaitu sebanyak 163 unit, yang terdiri dari 138 koperasi aktif dan 25 koperasi tidak aktif peneliti mengambil koperasi simpan pinjam yang berdiri di daerah tegallalang berjumlah 23 unit, penelitian ini diteliti karena koperasi simpan pinjam di Kecamatan Tegallalang Kabupaten Gianyar pada tahun 2018 salah satu koperasi simpan pinjam mengalami masalah kecurangan akuntansi yang mengakibatkan pegawai terlibat dalam kasus tersebut.

Penelitian Dewi (2014) yang berjudul pengaruh moralitas dan pengendalian intern pada kecurangan akuntansi mendapatkan hasil dimana individu dengan moralitas rendah tidak memperdulikan adanya pengendalian intern dalam kecuranagan, moralitas yang tinggi seorang individu terdapat pengendalian intern, kecurangan dilakukan cenderung dapat lebih rendah dengan kondisi yang tidak terdapat pengendalian intern. Artini et al., (2014) dalam penelitiannya yang berjudul pengaruh budaya etis organisasi dan efektivitas pengendalian intern terhadap kecenderungan kecurangan akuntansi pada satuan kerja perangkat daerah (SKPD) kabupaten Jembrana, mendapatkan kesimpulan dimana adanya pengaruh negatif dan signifikan antara budaya etis organisasi terhadap kecenderungan kecurangan akuntansi pada suatu SKPD. Penelitian menurut Fachrunisa et al., (2015), yang berjudul pengaruh keefektifan pengendalian intern, keadilan distributif, keadilan prosedural, dan budaya etis organisasi terhadap kecenderungan kecurangan akuntansi mendapatkan hasil bahwa budaya etis organisasi berpengaruh signifikan terhadap kecenderungan kecurangan akuntansi.

Penelitian Eliza (2015) dengan judul pengaruh moralitas individu dan pengendalian intern terhadap kecenderungan kecurangan akuntansi, mendapatkan hasil ternyata moralitas individu berpengaruh negatif dan signifikan terhadap tingkat kecenderungan kecurangan akuntansi. Mulia et al., (2017) dalam penelitian yang berjudul pengaruh moralitas individu dan pengendalian intern terhadap kecurangan, mendapatkan hasil dimana tidak terdapat perbedaan, dimana individu melakukan kecurangan dengan individu dengan moral tinggi dan moral rendah nilai signifikansi akan lebih besar dari alpha.

Penelitian Adelin (2013) dengan judul pengaruh pengendalian intern, ketaatan aturan akuntansi, dan perilaku tidak etis terhadap kecenderungan 
kecurangan akuntansi mendapat hasil dimana efektivitas pengendalian intern berpengaruh negative pada kecenderungan kecurangan akuntansi, pengendalian intern perusahaan yang semakin efektif akan mengakibatkan rendahnya kecurangan akuntansi.

Tujuan dari penelitian ini untuk mengetahui pengaruh moralitas individu, pengendalian intern, dan budaya etis organisasi pada kecenderungan kecurangan akuntansi. Penelitian ini diharapkan dapat memberikan manfaat teoritis agar dapat digunakan sebagai bahan masukan dan pertimbangan mengenai pengaruh moralitas individu, pengendalian intern, dan budaya etis organisasi terhadap kecenderungan kecurangan akuntansi. Untuk manfaat praktis diharapkan dapat memberikan informasi yang bermanfaat bagi pelaku koperasi agar lebih mengerti dan memahami mengenai kecurangan akuntansi.

Teori perkembangan moral dimaksud dimana nilai-nilai dan normanorma yang menjadi pegangan bagi seseorang atau suatu kelompok dalam mengatur tingkah lakunya. Welton et al., (1994) menyatakan individu mampu menyelasikan dilema etika dipengaruhi oleh level penalaran moralnya. Pada tahap konvensional individu mulai membentuk moralitas individunya dengan menaati peraturan, maka akhirnya terbentuk kematangan moral individu yang tertinggi pada tahap akhir yaitu tahap post-conventional. Kematangan moral yang tinggi pada individu ada pada tahapan post-conventional. Dalam merancang tanggapan dan sikap, kematangan moral merupakan dasar dan pertimbangannya. Pengetahuan moral menjadi dasar pembuatan keputusan yang etis dengan tangguang jawab sosial. Adanya tanggung jawab sosial, individu dengan moralitas yang tinggi diharapkan dapat mengurangi kecenderungan kecurangan akuntansi yang dilakukan staff perusahaan (Fauwzi, 2011).

Niat individu untuk melakukan suatu tindakan atau berperilaku dipengaruhi oleh beberapa faktor yaitu norma subyektif, sikap terhadap perilaku, dan persepsi kontrol perilaku menurut Theory of planned behavior. Perilaku Terencana dijelaskan juga dari Theory of Reasoned Action (TRA) dikembangkan (Ajzen, 1991). Menurut Ajzen niat untuk melakukan berbagai jenis perilaku dapat diprediksikan dengan singkat keakuratan yangg tinggi dari sikap seorang terhadap perilaku , norma subyektif, dan control perilaku yang disarankan.

Tindakan yang memiliki nilai positif yang menjadi istilah antar manusia dapat disebut dengan moral, dan manusia dengan tindakan yang tidak memiliki nilai positif disebut dengan amoral (Rahmawati, 2012). Menurut Fitri (2016) moral merupakan tindakan yang bernilai positif antar sesama manusia. Manajemen mempengaruhi sistem pengendalian intern dengan proses komprehensif untuk diberikan keyakinan yang sesuai dengan pedoman meningkatkan efektivitas dan efisiensi serta laporan keuangan yang andal dan patuh pada hukum (Randiza, 2016). Menurut Bertens (1993) moralitas (dari kata sifat latin moralis) mempunyai arti yang pada dasarnnya sama dengan "moral".

Budaya etis organisasi dikatakan sebagai persepsi bersama untuk organisasi agar menjadi system dan makna bagi anggota organisasi. Adanya hubungan yang erat antara budaya masyarakat dengan budaya organisasi (Sagiv \& Schwartz, 2007). Adapun nilai-nilai personal mulai dikembangkan pada 
saat awal kehidupan, seperti halnya kepercayaan pada umumnya, tersusun dalam sistem hirarki dengan sifat-sifat yang dapat dijelaskan dan diukur, serta konsekuensi - konsekuensi perilaku yang dapat diamati (Douglas et al., 2001).

Kecenderungan Kecurangan Akuntansi (KKA) keinginan melakukan sesuatu untuk mendapatkan keuntungan menggunakan cara tidak jujur. Dengan adanya tindakan dan kebijakan serta tindakan salah, menyembunyikan dan menyamarkan laporan keuangan untuk mendapatkan keuntungan pada diri sendiri (Amiruddin, 2017).

Moralitas merupakan bagaimana perilaku seseorang. Moral yang baik akan memperlihatkan perilaku nilai positif, moral yang tidak baik melakukan kecurangan yang akan merugikan dan membahayakan orang (Radhiah, 2016). Adanya level moral yang mempengaruhi kemampuan seorang individu (Puspasari \& Eko, 2012). Adanya penelitian yang berjudul sesuai dengan bahasan dimana moralitas individu berpengaruh terhadap kecenderungan kecurangan akuntansi, maka adanya pendapat dari penelitian menurut Artini et al., (2014) dan Eliza (2015) yang menyatakan bahwa moralitas individu berpengaruh negatif terhadap kecenderungan kecurangan akuntansi. Berdasarkan uraian tersebut, maka peneliti mengambil hipotesis yaitu :

$\mathrm{H}_{1}$ : Moralitas Individu berpengaruh negatif pada Kecenderungan Kecurangan

Akuntansi

Pengendalain intren berkaitan dengan beberapa tujuan kategori dimana ada efektivitas dan efisien kegiatan, laporan keuangan serta taat dengan peraturan yang berlaku (Karyono, 2013). Pengendalian intern penting untuk entitas, dimana memberikan perlindungan pada entitas dari kelemahan manusia serta mengurangi tindakan untuk melakukan kecurangan yang tidak sesuai dengan aturan (Fitri, 2016). Adanya penelitian yang berjudul sesuai dengan bahasan dimana pengendalian intern berpengaruh terhadap kecenderungan kecurangan akuntansi, dimana penelitian menurut Eliza (2015), Adelin (2013), dan Zainal (2013) mendapatkan hasil bahwa pengendalian intern berpengaruh negatif terhadap kecenderungan kecurangan akuntansi . Berdasarkan uraian tersebut, maka peneliti mengambil hipotesis yaitu:

$\mathrm{H}_{2}$ : Pengendalian Intern berpengaruh negatif pada Kecenderungan Kecurangan

Akuntansi

Budaya etis dalam organisasi berpengaruh terhadap pola pikir, bertindak dan berperilaku pada orang yang ada di organisasi ttersebut. Budaya oorganisasi mempengaruhi perilaku seseorangg untuk berperilaku etis dan tidak etis. Suatu organisasi dengan budaya yang buruk akan mempengaruhi orang yang ada didalamnya untuk melakukan kecurangan. Adanya hasil penelitian yang sesuai dengan bahasan, dimana penelitian Artini et al., (2014) dan Novirianti et al., (2015) mendapatkan hasil bahwa budaya etis organisasi berpengaruh negatif terhadap kecenderungan kecurangan akuntansi. Berdasarkan uraian tersebut, maka peneliti mengambil hipotesis yaitu :

$\mathrm{H}_{3}$ : Budaya Etis Organisasi berpengaruh negatif pada Kecenderungan Kecurangan Akuntansi 


\section{METODE PENELITIAN}

Penelitian ini bertujuan untuk menguji moralitas individu, pengendalian intern dan budaya etis organisasi pada kecenderungan kecurangan akuntansi. Lokasi penelitian ini dilakukan di Koperasi simpan pinjam di Kecamatan Tegallalang. Waktu penelitian ini yaitu tahun 2019. Populasi penelitian ini yaitu pegawai, tidak dibatasi oleh jabatannya.

Pengambilan sampel dilakukan dengan purposive sampling. Data primer yang didapatkan darikuisioner yang dibagikan ke responden dan data sekunder yang digunakan dalam penelitian ini. Olah data dengan alat statistic SPSS. Teknik analisis yang dilakukan adalah regresi linear berganda. Ada beberapa item pertanyaan yang digunakan dalam instrument penelitian untuk variable-variabel. Data yang telah terkumpul dari kuisioner dilanjutkan uji validitas dan reliabilitas.

Berdasarkan uraian tersebut, akan terlihat bagaimana moralitas individu, pengendalian intern dan budaya etis organisasi pada kecenderungan kecurangan akuntansi yang kemudian akan diambil kesimpulan berdasarkan data yang telah diperoleh. Skema desain penelitian dapat dilihat pada Gambar 1.

Pengaruh Moralitas Individu, Pengendalian Intern dan Budaya Etis Organisasi Terhadap Kecenderungan Kecurangan Akuntansi Pada Koperasi Simpan Pinjam di Kecamatan Tegallalang

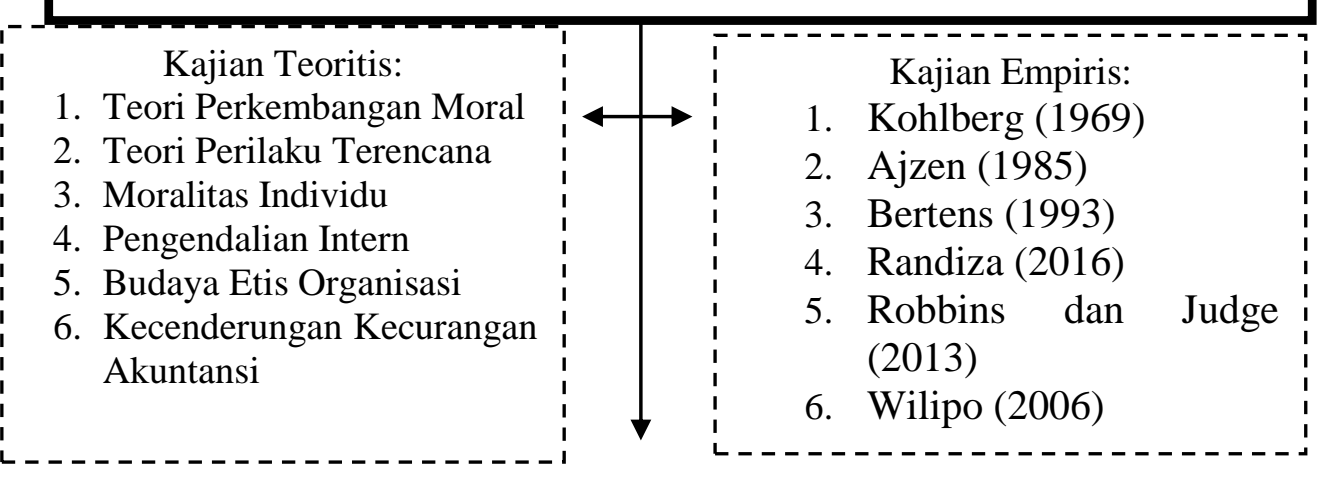

Variabel Penelitian :

Kecenderungan Kecurangan Akuntansi (Y), Moralitas Individu $\left(\mathrm{X}_{1}\right)$, Pengendalian Intern $\left(\mathrm{X}_{2}\right)$, Budaya Etis Organisasi $\left(\mathrm{X}_{3}\right)$

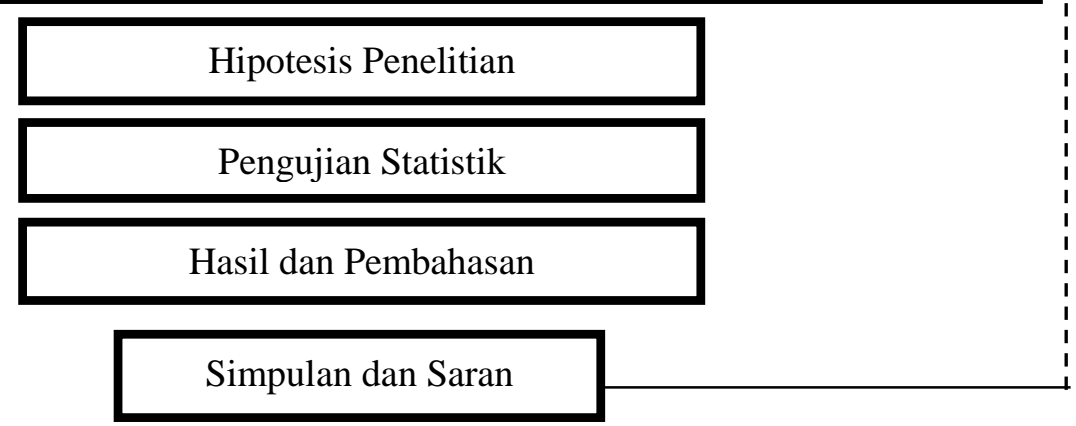

Gambar 1. Desain Penelitian

Sumber : Data Penelitian, 2018 
Variabel moralitas individu mengukur dengan tiga pernyataan indikator yaitu pra-conventional, conventional, dan post conventional (Sanuari, 2014) menggunakan skala likert 1-5. Setiap instrument pertanyaan mewakili sebuah indikator yang mengukur setiap tahapan moralitas individu. Variabel pengendalian intern ini diukur dengan 5 pernyataan indikator yaitu lingkungan pengendalian, penilaian resiko, kegiatan pengendalian, informasi dan komunikasi, serta pemantau dengan menggunakan skala likert 1-5. Instrumen yang digunakan untuk mengukur budaya etis organisasi terdiri dari konsiderasi. Consideration (konsiderasi) adalah gaya kepemimpinan yang menggambarkan kedekatan hubungan antara bawahan dengan atasan, adanya saling percaya, kekeluargaan, menghargai gagasan bawahan, dan adanya komunikasi antara pimpinan dengan bawahan.

Indikator yang digunakan di variabel kecenderungan kecurangan akuntansi adalah kecenderungan untuk melakukan manipulasi, pemalsuan, atau perubahan catatan akuntansi atau dokumen pendukungnya, kecenderungan untuk melakukan penyajian yang salah atau penghilangan peristiwa, transaksi, atau informasi yang signifikan dari laporann keuangan, kecenderungan untuk melakukan salah menerapkan prinsip akuntansisecara sengaja, kecenderungan untuk melakukan penyajian laporan keuangan yang salah akibat pencurian (penyalahgunaan/ penggelapan) terhadap aktiva yang membuat entitas membayar barang/jasa yang tidak terima dan kecenderungan untuk melakukann penyajian laporan keuangan yang salah akibat perlakuan yang tidak semestinya terhadap aktiva dan disertai dengan catatan atau dokumen palsu dan dapat menyangkut satu atau lebih individu di antara manajemen, karyawan atau pihak ketiga yang dikembangkan oleh penelitian Finty (2016) dengan menggunakan skala likert 1-5.

Untuk mengetahui apakah variabel independen memengaruhi variabel dependen pada penelitian ini digunakan persamaan regresi linear berganda. Analisis regresi linear berganda (multiple linear regression) digunakan untuk variabel atau lebih. Adapun model regresi linear berganda dengan persamaan sebagai berikut:

$Y=\beta_{0}+\beta_{1} X_{1}+\beta_{2} X_{2}+\beta_{3} X_{3}+\varepsilon$

Keterangan :

$$
\begin{aligned}
& \mathrm{Y} \quad=\text { Kecenderungan Kecurangan Akuntansi } \\
& \mathrm{X}_{1} \quad=\text { Moralitas Individu } \\
& \mathrm{X}_{2} \quad=\text { Pengendalian Intern } \\
& X_{3} \quad=\text { Budaya Etis Organisasi } \\
& \beta_{1}, \beta_{2}, \beta_{3} \quad=\text { Koefisien regresi variabel } X_{1}, X_{2}, X_{3} \text {, } \\
& \varepsilon=\text { Eror }
\end{aligned}
$$

\section{HASIL DAN PEMBAHASAN}

Statistik deskriptif dalam penelitian ini bertujuan untuk mendeskripsikan masing-masing variabel berdasarkan data yang diperoleh dari hasil penyebaran kuisioner penelitian. Analisis deskriptif dilakukan untuk mengetahui 
karakteristik dan tanggapan responden terhadap masing-masing pernyataan. Seluruh variabel dideskripsikan dengann mmenggunakan nilai rata-rata. Penilaian distribusi data setiap variabel menggunakan rentang kriteria yang dihitung dengan persamaan:

$$
\begin{aligned}
\text { Nilai Interval } & =\frac{(\text { Nilai batas tertinggi }- \text { nilai batas terendah })}{\text { Total nilai yang digunakan }} . \\
& =\frac{(5-1)}{5}=0,8
\end{aligned}
$$

Berdasarkan hasil interval range maka dapat disusun kriteria hasil pengukuran konstruk dalam Tabel 1 sebagai berikut:

Tabel 1. Kriteria Skor Variabel Penelitian

\begin{tabular}{cc}
\hline Nilai Skor & Kriteria Skor Penilaian \\
\hline $1,00-1,80$ & Sangat tidak baik / Sangat Rendah \\
$>1,80-2,60$ & Tidak baik / Rendah \\
$>2,60-3,40$ & Cukup Baik / Sedang \\
$>3,40-4,20$ & Baik / Tinggi \\
$>4,20-5,00$ & Sangat baik / Sangat Tinggi \\
\hline
\end{tabular}

Sumber : Data Penelitian, 2019

Pengumpulan data dilakukan dengan kuisioner disebarkan sebanyak 92 kuisioner dalam 23 KSP Kecamatan Tegallalang, total kuisioner yang kembali sebanyak 72 buah eksemplar. Hasil uji validitas dari setiap variabel mendapatkan nilai koefisien korelasi dengan skor total seluruh item pernyataan lebih besar dari 0,30 dengan signifikansi kurang dari 0,05. Hasil uji reliabilitas instrumen dimana nilai alpha cronbach dinyatakan reliabel dengan nilai yang lebih besar 0,60. Hasil uji statistik deskriptif dapat dilihat pada Tabel 2. Tabel 2. Statistik Deskriptif Variabel Penelitian

Std.

\begin{tabular}{lrrrrr} 
& N & Minimum & Maximum & Mean & Deviation \\
\hline Moralitas Individu & 72 & 6.00 & 15.00 & 11.055 & 2.396 \\
Pengendalian Intern & 72 & 65.00 & 129.00 & 98.638 & 15.954 \\
Budaya Etis Organisasi & 72 & 11.00 & 25.00 & 18.597 & 3.551 \\
Kecenderungan & 72 & 16.00 & 47.00 & 31.680 & 8.962 \\
Kecurangan Akuntansi & & & & & \\
Valid N (listwise) & 72 & & & & \\
\hline
\end{tabular}

Sumber : Data Penelitian, 2019

Hasil statistik deskriptif variabel moralitas individu memiliki total minimum sebesar 6 dan total maksimum sebesar 15 dengan rata-rata 11,055 yang. Variabel pengendalian intern memiliki total minimum sebesar 65 dan total maksimum sebesar 129 dengan rata-rata 98,638. Variabel budaya etis organisasi memiliki total minimum sebesar 11 dan total maksimum sebesar 25 dengan ratarata 18,597. Variabel kecenderungan kecurangan akuntansi memiliki total minimumm sebesar 16 dan total maksimum sebesar 47 dengan rata-rata 31,680 .

Hasil uji asumsi klasik yang dipenuhi pada analisis regresi linear sederhana antara lain Uji Normalitas menunjukkan nilai signifikansi sebesar 0,361 dapat disimpulkan bahwa model persamaan regresi dalam penelitien ini sudah berdistribusi normal. Uji Multikolinearitas menunjukkan bahwa nilai tolerance untuk setiap variabel lebih besar dari $10 \%$ dan nilai VIF lebih kecil dari 
10 yang berartii mmodel persamaan regresi bebas dari uji multikolinearitas. Uji Heteroskedastisitas menunjukkan bahwa nilai signifikansi dari variabel moralitas individu sebesar 0,205 , nilai signifikansi variabel pengendalian intern sebesar 0,758, dan nilai signifikansi variabel budaya etis organisasi sebesar 0,534 berarti setiap variabel independen tidak terdapat pengaruh antara variabel bebas terhadap absolute residual maka model yang dibuat tidak mengandung gejala heterokedastisitas.

Berdasarkan hasil dari semua uji asumsi klasik sudah terpenuhi maka hasil analisis regresi layak dilanjutkan. Hasil analisis regresi linier berganda didapatkan hasil yang telah di uji menggunakan SPSS yang disajikan pada Tabel 3.

Tabel 3. Hasil Analisis Regresi Linier Berganda

\begin{tabular}{|c|c|c|c|c|c|}
\hline \multirow[t]{2}{*}{ Model } & \multicolumn{2}{|c|}{$\begin{array}{c}\text { Unstandardized } \\
\text { Coefficients }\end{array}$} & \multirow{2}{*}{$\begin{array}{c}\begin{array}{c}\text { Standardized } \\
\text { Coefficients }\end{array} \\
\text { Beta }\end{array}$} & \multirow[b]{2}{*}{$\mathrm{T}$} & \multirow[b]{2}{*}{ Sig. } \\
\hline & $\mathrm{B}$ & Std. Error & & & \\
\hline 1 (Constant) & 84.741 & 1.330 & & 63.738 & .000 \\
\hline Moralitas individu & -0.470 & 0.156 & -0.126 & -3.014 & .004 \\
\hline Pengendalian intern & -0.329 & 0.028 & -0.586 & -11.601 & .000 \\
\hline Budaya etis organisasi & -0.828 & 0.104 & -0.328 & -7.921 & .000 \\
\hline R Square & \multicolumn{5}{|c|}{0,963} \\
\hline Adjusted R Square & \multicolumn{5}{|c|}{0,961} \\
\hline F hitung & \multicolumn{5}{|c|}{584,484} \\
\hline Signifikansi F & \multicolumn{5}{|c|}{0,000} \\
\hline
\end{tabular}

Sumber : Data Penelitian, 2019

Hasil analisis regresi linier berganda disajikan pada Tabel 2, maka dapat dibuat persamaan regresi sebagai berikut:

$$
\mathrm{Y}=84,741-0,470 \mathrm{X}_{1}-0,329 \mathrm{X}_{2}-0,828 \mathrm{X}_{3}+\mathrm{e}
$$

Nilai koefisien regresi setiap variabel mendapatkan hasil negatif dan nilai signifikansi uji t kurang dari 0,05, maka semua variabel bebas memiliki pengaruh negatif terhadap variabel terikat.

Hasil uji koefisien determinasi $\left(R^{2}\right)$ besarnya pengaruh variabel bebas terhadap variabel terikat yang ditunjukkan olehh nilai determinasi total (Adjusted $R$ Square) sebesar 0,961 mempunyai arti bahwa sebesar 96,1\% variasi kecenderungan kecurangan akuntansi pada KSP di Kecamatan Tegallalang dipengaruhi oleh variasi moralitas individu, pengendalian intern, dan budaya etis organisasi, sedangkan sisanya sebesar 3,9\% djelaskan oleh faktor lain yang tidak dimasukkan ke dalam model.

Hasil uji kelayakan model (uji F) menunjukkan nilai $F_{\text {hitung sebesar } 584,484}$ dengan signifkansi sebesar 0,000 <0,05, maka dapat disimpulkan bahwa pada kelompokk yang diujimemiliki perbedaan yyang nyata (signifikan). Hasill ini mempunyai arti bahwa ada secara simultan moralitas individu, pengendalian intern, dan budaya etis organisasi, berpengaruh signifikan terhadap kecenderungan kecurangan akuntansi pada KSP di Kecamatan Tegallalang.

Hasil uji hipotesis (uji $t$ ) untuk $\mathrm{H}_{1}$ dimana pengaruh moralitas individu pada kecenderungan kecurangan akuntansi, dengan hasil analisis pengaruh moralitas individu terhadap Kecenderungan kecurangan akuntansi diperoleh nilai signifikasi sebesar 0,004 dengan nilai koefisien regresi negatif sebesar -0,470. Nilai Signifikansi 0,004<0,05 mengindikasikan bahwa $\mathrm{H}_{1}$ diterima. Hasil ini 
mempunyai arti bahwa moralitas individu berpengaruh negatif dan signifikan terhadap kecenderungan kecurangan akuntansi. Untuk $\mathrm{H} 2$ dimana pengaruh pengendalian intern pada kecenderungan kecurangan akuntansi, dengan hasil analisis pengaruh pengendalian intern terhadap kecenderungan kecurangan akuntansi diperoleh nilai signifikansi sebesar 0,000 dengan nilai koefisien regresi negatif sebesar $-0,329$. Nilai Signifikansi 0,000<0,05 mengindikasikan bahwa $\mathrm{H}_{2}$ diterima. Hasil ini mempunyai arti bahwa pengendalian intern berpengaruh negatif dan signifikan terhadap kecenderungan kecurangan akuntansi. Untuk $\mathrm{H3}$ dimana pengaruh budaya etis organisasi pada kecenderungan kecurangan akuntansi, dengan hasil analisis pengaruh Budaya etis organisasi terhadap Kecenderungan kecurangan akuntansi diperoleh nilai signifikansi sebesar 0,000 dengan nilai koefisien regresi negatif sebesar $-0,828$. Nilai signifikansi $0,000<$ 0,05 mengindikasikan bahwa $\mathrm{H}_{3}$ diterima. Hasil ini mempunyai arti bahwa budaya etis organisasi berpengaruh negatif dan signifikan kecenderungan kecurangan akuntansi.

Hasil analisis menunjukkan bahwa moralitas individu berpengaruh negatif dan signifikan terhadap kecenderungan kecurangan akuntansi. Hal ini berarti semakin baik moralitas individu yang dimiliki oleh karyawan, maka tingkat kecenderungan kecurangan akuntansi pada KSP di Kecamatan Tegalalang akan semakin rendah. Begitu pula sebaliknya, semakin buruk moralitas individu yang dimiliki oleh karyawan, maka tingkat kecenderungan kecurangan akuntansi pada KSP di Kecamatan Tegalalang akan semakin meningkat. Hasil penelitian ini sesuai dengan penelitian Artini et al., (2014), Eliza (2015), Liyanarachi \& Newdick (2009), Puspasari \& Eko (2012), dan Radhiah (2016) yang memperoleh hasil bahwahmoralitas individudberpengaruh negatifdterhadap kecenderungandkecurangan aakuntansi.

Hal ini berarti level penalaran moral individu mereka akan mempengaruhi perilaku etis imereka. Orang dengan level penalaran moral yang rendah berperilaku beberapa dengan orang yang memiliki level penaralan moral yang tinggi ketika menghadapi dilema etika, dan semakin tinggi level penalaran seseorang maka individu tersebut semakin mungkin untuk melakukan hal yang benar. Penelitian ini juga berpendapat bahwa moralitas individu akan mempengaruhi kecenderungan seseorang melakukan kecurangan akuntansi. Dengan demikian dapat disimpulkan bahwa semakin tinggi moralitas individu, semakin ia akan berusaha untuk menghindari diri dari kecenderungan kecurangan akuntansi.

Hasil analisis dalam penelitian ini menunjukkan bahwa sistem pengendalian intern berpengaruh negatif dan signifikan terhadap kecenderungan kecurangan akuntansi. Hal ini berarti semakin baik pelaksanaan pengendalian intern pada KSP di Kecamatan Tegallalang, maka akan dapat memotivasi karyawan untuk bekerja dengan baik sehingga dapat mengurangi tingkat kecenderungan kecurangan akuntansi yang terjadi. Begitu pula sebaliknya, semakin buruk pelaksanaan pengendalian intern pada KSP di Kecamatan Tegallalang, maka kecenderungan kecurangan akuntansi yang dihasilkan akan semakin meningkat. Pengendalian intern sangat penting bagi suatu entitas, antara lain untuk memberikan perlindungan terhadap 
suatu entitas dari kelemahan manusia serta mengurangi tindakan untuk melakukan kecurangan yang tidak sesuai dengan aturan (Fitri, 2016).

Hasil penelitian ini juga sejalan dengan penelitian Kusumastuti (2012), Adelin (2013), Karyono (2013) dan Zainal (2013) yang memperoleh hasil bahwa evektifitas pengendalian intern berpengaruh negatif terhadap kecurangan akuntansi. Hal ini berarti bahwa kecenderungan kecurangan akuntansi dapat dikurangi jika sistem pengendalian intern yang efektif diterapkan dalam perusahaan. Semakin tinggi sistem pengendalian intern maka semakin menurun kecenderungan kecurangan akuntansi.

Hasil analisis dalam penelitian ini menunjukkan bahwa Budaya etis organisasi berpengaruh negatif dan signifikan terhadap kecenderungan kecurangan akuntansi. Hal ini berarti semakin baik penerapan budaya etis organisasi pada KSP, maka akan dapat mengurangi tingkat kecenderungan kecurangan akuntansi yang terjadi pada KSP di Kecamatan Tegallalang. Begitu pula sebaliknya, semakin buruk penerapan budaya etis organisasi pada KSP, maka kecenderungan kecurangan akuntansi yang dihasilkan akan semakin meningkat.

Hasil penelitian ini mendukung temuan penelitian Novirianti et al., (2015) dan Artini et al., (2014) yang menyatakan bahwa budaya etis organisasi berpengaruh negatif signifakan terhadap kecenderungan kecurangan akuntansi. Jika semakin tinggi budaya etis organisasi, makan kecenderungan kecurangan (fraud) semakin rendah. Hal ini disebabkan karena budaya etis dalam suatu organisasi sangat mempengaruhi pola pikir, cara bertindak dan cara berperilaku orang-orang yang berada didalam organisasi tersebut. Dimana budaya organisasi memberikan pengaruh yang besar terhadap perilaku seseorang baik untuk berperilaku etis maupun untuk berperilaku tidak etis. Budaya organisasi yang buruk akan sangat memicu orang-orang yang beradaa didalam organisasi tersebut uuntuk melakukan hal-hal yang menyimpang ataupun melakukan kecurangan karena hal tersebut dianggap lumrah atau layak untuk dilakukan bagi anggota organisasi. Sedangkan jika budaya organisasi yang ditanamkan baik, maka hal tersebut akan memberikan dampak yang baik bagi anggotadorganisasi, sehingga dapat meminimalisir terjadingan kecenderungan kecurangan yang terjadi.

Hasil penelitian menunjukkan bahwa moralitas individu, pengendalian intern, dan budaya etis organisasi memberikan pengaruh yang negatif dan signifikan terhadap kecenderungan kecurangan akuntansi. Implikasi dari hasil penelitian mampu menjadikan tambahan pengetahuan, referensi dan bahan pertimbangan bagi pihak Koperasi Simpan Pinjam di Kecamatan Tegallalang dalam proses pengambilan keputusan dan penetapan kebijakan perusahaan untuk meminimalisir terjadinya kecenderungan kecurangan akuntansi.

Karyawan KSP di Kecamatan Tegallalang perlu ditanamkan moralitas yang baik melalui pendidikan dan pelatihan. Selain itu, pengendalian intern budaya etis organisasi juga menjadi salah satu faktor yang sangat menentukan terjadinya kecenderungan kecurangan, sehingga penting bagi perusahaan untuk meningkatkan pengendalian intern dan menerapkan budaya etis organisasi yang baik, sehingga semangat kerja karyawan akan meningkat dan karyawan mampu 
menghasilkan laporan akuntansi yang berkualitas dan tidak melakukan kecurangan. Kemudian dengan meningkatkan pengendalian intern dan budaya etis organisasi yang baik, akan dapat membuat setiap pekerjaan dan tanggung jawab yang diberikan dapat dilaksanakan dengan baik oleh karyawan. Jika moralitas individu, pengendalian intern, dan budaya etis organisasi ini mampu diterapkan dan dijalankan dengan baik, maka semangat kerja karyawan akan meningkat yang nantinya akan memberikan dampak yang sangat besar untuk meminimalisir kecenderungan kecurangan akuntansi yang terjadi pada KSP di Kecamatan Tegallalang.

\section{SIMPULAN}

Berdasarkan hasil penelitian yang dijelaskan, maka didapatkan simpulan dimana Moralitas individu berpengaruh negatif terhadap kecenderungan kecurangan akuntansi. Hal ini berarti semakin baik moralitas individu yang dimiliki oleh karyawan, maka tingkat kecenderungan kecurangan akuntansi pada KSP di Kecamatan Tegalalang akan semakin rendah. Pengendalian intern berpengaruh negatif terhadap kecenderungan kecurangan akuntansi. Hal ini berarti bahwa semakin baik pelaksanaan pengendalian intern pada KSP di Kecamatan Tegallalang, maka akan dapat memotivasi karyawan untuk bekerja dengan baik sehingga dapat mengurangi tingkat kecenderungan kecurangan akuntansi yang terjadi. Budaya etis organisasi berpengaruh negatif terhadap kecenderungan kecurangan akuntansi. Hal ini berarti semakin baik penerapan budaya etis organisasi pada KSP, maka akan dapat mengurangi tingkat kecenderungan kecurangan akuntansi yang terjadi pada KSP di Kecamatan Tegallalang.

Meminimalisir terjadinya kecenderungan kecurangan akuntansi, maka KSP di Kecamatan Tegalalang perlu meningkatkan moralitas individu, pengendalian intern, dan budaya etis organisasi karyawannya dengan cara memberikan pendidikan karakter dan pendidikan moral yang baik dalam bekerja. Dengan hasil negatif yang didapat peneliti selanjutnya dapat mengembangkan di setiap koperasi yang ada. Penelitian selanjutnya juga disarankan untuk memperluas wilayah penelitian agar hasil dalam penelitian dapat digeneralisir pada seluruh KSP di Provinsi Bali.

\section{REFERENSI}

Adelin, V. (2013). Pengaruh Pengendalian Internal, Ketaatan Aturan Akuntansi, dan Perilaku Tidak Etis Terhadap Kecenderungan Kecurangan Akuntansi (Studi Empiris pada BUMN di Kota Padang). Skripsi Universitas Negeri Padang.

Ajzen, I. (1991). Organizational Behavior and Human Decision Process.

Amiruddin. (2017). The performance of goverment auditors in perspectives ethical behavior and tendency of accounting fraud. IOSR Journal of Economics and Finance (IOSR-JEF), 8(4), 35-42.

Artini, E. A., Pradana, A., dan Trisna, H. (2014). Pengaruh Budaya Etis Organisasi Dan Efektifitas Pengendalian Internal Terhadap Kecenderungan Kecurangan Akuntansi Pada Satuan Kerja Perangkat Daerah (SKPD) Kabupaten Jemrana. E-Journal Universitas Pendidikan Ganesha, 2(1). 
Bertens, K. (1993). The Pstmodern Weltanschauung and relation to modernism: an introductory survey. A Postmodern Reader, 25-70.

Dewi, G. A. K. R. S. (2014). Pengaruh Moralitas Individu dan Pengendalian Internal pada Kecurangan Akuntansi (Studi Eksperimen pada Pemerintah Daerah Provinsi Bali). Tesis Universitas Udayana.

Douglas, P. C., Ronald, A. D., and Shwartz, B. N. (2001). The Effect of Organizational Culture and Ethical Orientation on Accountants Ethical Judgements. Journal of Business Ethics, 34, 101-121.

Eliza, Y. (2015). Pengaruh Moralitas Individu Dan Pengendalian Internal Terhadap Kecenderungan Kecurangan Akuntansi (Studi Empiris Pada Skpd Di Kota Padang). Jurnal Akuntansi, 4(1).

Fachrunisa, A., Amir, H., dan Devi, S. (2015). Pengaruh Keefektifan Pengendalian Internal, Keadilan Distributif, Keadilan Prosedural, dan Budaya Etis Organisasi terhadap Kecenderungan Kecurangan Akuntansi. Jom FEKON, 2(2), 1-15.

Fauwzi. (2011). Analisis Pengaruh Keefektifan Pengendalian Internal, Persepsi Kesesuaian Kompensasi, Moralitas Manajemen Terhadap Perilaku Tidak Etis dan Kecenderungan Kecurangan Akuntansi. Jurnal Akuntansi Universitas Diponegoro.

Finty, U. (2016). Pengaruh Pengendalian Internal dan Moralitas Individu Pada Kecenderungan Kecurangan Akuntansi (Studi pada Villa di Kawasan Umalas). Skripsi Fakultas Ekonomi Dan Bisnis Universitas Udayana.

Fitri, Y. (2016). Pengaruh keefektifan sistem pengendalian internal, ketaatan akuntansi, asimteri informasi dan moralitas individu terhadap kecenderungan kecurangan akuntansi dengan perilaku tidak etis sebagai variabel intervening (Studi empiris pada Satuan Kerja Perangkat. Jom Fekon, $3(1)$.

Karyono. (2013). Forensic Fraud (1st ed.). Yogyakarta: Andi.

Kumaat, V. (2011). Internal Audit. Jakarta: Erlangga.

Kusumastuti, N. R. (2012). Analisis Faktorfaktor yang Berpengaruh terhadap Kecenderungan Kecurangan Akuntansi dengan Perilaku Tidak Etis Sebagai Variabel Intervening. Skripsi Universitas Diponogoro.

Liyanarachi, G., and Newdick, C. (2009). The Impact of Moral Reasoning and Retaliation on Whistle-Blowing: New-Zealand Evidence. Journal of Business Ethics, 89.

Mulia, H. K., Rahmat, F., dan Rayna, K. (2017). Pengaruh Moralitas Individu dan Pengendalian Internal terhadap Kecurangan: Sebuah Studi Eksperimental. Jurnal Akuntansi Dan Investasi, 18(2), 198-208.

Novirianti, K., Darmawan, N. A., dan Werastuti, D. N. (2015). Pengaruh Budaya Etis Organisasi dan Moralitas Aparat Terhadap Kecenderungan Kecurangan Akuntansi(Studi Empiris Pada SKPD Kabupaten Jembrana). Jurnal Ilmiah Mahasiswa Akuntansi Undiksha, 3(1).

Prawira. (2014). Pengaruh Moralitas Individu,Asimetri Informasi, dan Efektivitas Pengendalian Internal Terhadap Kecenderungan Kecurangan (FRAUD) Akuntansi. E-Journal Universitas Pendidikan Ganesha, 2(1).

Pristiyanti, I. R. (2012). Persepsi Pegawai Instansi Pemerintah Mengenai FaktorFaktor Yang Mempengaruhi Fraud Di Sektor Pemerintahan. Accounting 
Analysis Journal, 1(1).

Puspasari, N., dan Eko, S. (2012). Pengaruh Moralitas Individu Dan Pengendalian Internal Terhadap Kecenderungan Kecurangan Akuntansi: Studi Eksperimen Pada Konteks Pemerintahan Daerah.

Radhiah, T. (2016). Pengaruh Keefektivan Pengendalian Internal, Kesesuaian Kompensasi, dan Moralitas Individu terhadap Kecenderungan Kecurangan Akuntansi. JOM Fekon, 3(1), 1279-1293.

Rahmawati, A. P. (2012). Analisis Pengaruh Faktor Internal dan Moralitas Manajemen Terhadap Kecenderungan Kecurangan Akuntansi. Tesis Universitas Diponegoro.

Randiza, I. (2016). Pengaruh pengendalian internal, asimetri informasi, moralitas aparat pemerintah dan ketaatan aturan terhadap kecenderungan kecurangan akuntansi (Studi kasus pada SKPD Kab. Indragiri Hilir). Jom FEKON, 3(1).

Sagiv, L., and Schwartz. (2007). Cultural values in Organisations: Insights for Europe. European Journal International Management, 1(3), 176-190.

Sanuari, N. (2014). Pengaruh Sistem Pengendalian Internal, Kesesuaian Kompensasi, Dan Moralitas Manajemen Terhadap Kecenderungan Kecurangan Akuntansi. Jurnal Fakultas Ekonomi Universitas Negeri Padang.

Thoyibatun, S. (2012). Faktor-faktor yang berpengaruh terhadap Perilaku Tidak Etid fan Kecenderungan Kecurangan Akuntansi Serta Akibatnya terhadap Kinerja Organisasi. Jurnal Ekonomi Dan Keuangan, 16(2), 245-260.

Welton, R., Davis, R., and Lagroune, M. (1994). Promoting The Moral Development Of Accounting Graduate Students. Accounting Education International Journal, 3, 98.

Widiyaswari. (2017). Pengaruh Keefektifan Pengendalian Internal, Kesesuaian Kompensasi, dan Budaya Organisasi terhadap Kecenderungan Kecurangan (FRAUD) pada Lembaga Pengkreditan Desa (LPD) Se-Kecamatan Susut. EJournal Universitas Pendidikan Ganesha, 8(2).

Widjaja, A. T. (2013). Pengendalian Internal; Mencegah dan Mendeteksi Kecurangan. Jakarta: Harvarindo.

Zainal, R. (2013). Pengaruh Efektivitas Pengendalian Intern, Asimetri Informasi Dan Kesesuaian Kompensasi Terhadap Kecenderungan Kecurangan Akuntansi (FRAUD) (Studi Empiris Kantor Cabang Bank Pemerintahan Dan Swasta Di Kota Padang). Skripsi Universitas Negeri Padang. 